\title{
PENYELENGGARAAN SISTEM ELEKTRONIK DALAM SISTEM HUKUM ADMNISTRASI NEGARA BERDASARKAN UU ITE NO. 11 TAHUN 2008 JO UU NO. 19 TAHUN 2106
}

\author{
M. Tohir \\ tohir@unitaspalembang.ac.id \\ Fakultas Hukum Universitas Tamansiswa Palembang, Indonesia
}

\begin{abstract}
Abstrak: Menurut UU No. 11 Tahun 2008 Jo UU No. 19 Tahun 2006 tentang ITE bahwa Penggunaan dan pemanfaatan Teknologi Informasi harus terus dikembangkan untuk menjaga, memelihara, dan memperkukuh persatuan dan kesatuan nasional berdasarkan Peraturan Perundangundangan demi kepentingan nasional. Dan tujuannya haruslah didukung oleh pemerintah melalui pengembangan Teknologi Informasi dan infrastruktur hukum dan pengaturannya sehingga pemanfaatan Teknologi Informasi dilakukan secara aman untuk mencegah penyalahgunaannya dengan memperhatikan nilai-nilai agama dan sosial budaya masyarakat Indonesia. Permasalahannya adalah Apakah arti tindakan/perbuatan hukum dalam sistem hukum administrasi negara ! dan Bagaimana peranan sistem elektronik dan informasi dalam penyelenggaraan sistem hukum administrasi negara ? Tindakan/Perbuatan Hukum dalam Sistem Hukum Administrasi Negara adalahsetiap tindakan/perbuatan alat perlengkapan pemerintah (Bestuurs organ) dalam lapangan hukum tata pemerintahan untuk pemeliharaan kepentingan rakyat dalam bidang hukum publik dan privat dengan wewenang luar biasa dari Undang-undang baik itu bersegi satu, dua dan segi banyak.Peranan Sistem Elektronik dan Informasi dalam Penyelenggaraan Sistem Hukum Administrasi Negara adalah pemanfaatan sistem teknologi informasi, dokumen elektronik dan sertifikat elektronik dengan prinsip yuridis, sosiologis dan filosofis.
\end{abstract}

Kata kunci: Sistem administrasi negara, sistem elektronik, Dokumen elektronik

Abstrak: Menurut UU No. 11 Tahun 2008 Jo UU No. 19 Tahun 2006 tentang ITE bahwa Penggunaan dan pemanfaatan Teknologi Informasi harus terus dikembangkan untuk menjaga, memelihara, dan memperkukuh persatuan dan kesatuan nasional berdasarkan Peraturan Perundangundangan demi kepentingan nasional. Dan tujuannya haruslah didukung oleh pemerintah melalui pengembangan Teknologi Informasi dan infrastruktur hukum dan pengaturannya sehingga pemanfaatan Teknologi Informasi dilakukan secara aman untuk mencegah penyalahgunaannya dengan memperhatikan nilai-nilai agama dan sosial budaya masyarakat Indonesia. Permasalahannya adalah Apakah arti tindakan/perbuatan hukum dalam sistem hukum administrasi negara ! dan Bagaimana peranan sistem elektronik dan informasi dalam penyelenggaraan sistem hukum administrasi negara ? Tindakan/Perbuatan Hukum dalam Sistem Hukum Administrasi Negara adalahsetiap tindakan/perbuatan alat perlengkapan pemerintah (Bestuurs organ) dalam lapangan hukum tata pemerintahan untuk pemeliharaan kepentingan rakyat dalam bidang hukum publik dan privat dengan wewenang luar biasa dari Undang-undang baik itu bersegi satu, dua dan segi banyak.Peranan Sistem Elektronik dan Informasi dalam Penyelenggaraan Sistem Hukum Administrasi Negara adalah pemanfaatan sistem teknologi informasi, dokumen elektronik dan sertifikat elektronik dengan prinsip yuridis, sosiologis dan filosofis.

Kata kunci: Sistem administrasi negara, sistem elektronik, Dokumen elektronik 


\section{LATAR BELAKANG}

Penyelenggaraan sistem elektronik dalam sistem hukum administrasi negara merupakan salah satu komponen sistem hukum dan administrasi negara. Sistem elektronik adalah bentuk teknis yang dipakai dalam penyelenggaraan hukum administrasi negara. Dalam sistem hukum terdiri atas norma-norma hukum seperti peraturan-peraturan yang satu sama lain saling berkaitan dan mempengaruhi karena merupakan suatu sistem hukum yang utuh. Sistem hukum sebagaimana dijelaskan oleh Ishaq dalam bukunya Dasar-dasar Ilmu hukum bahwa Sistem hukum di Indonesia merupakan sistem hukum positif lainnya terdiri atas subsistem hukum pidana, hukum perdata, hukum tata negara, hukum administarsi negara dan sebagainya. ${ }^{1}$

Berdasarkan ketentuan dalam Undang-Undang Republik Indonesia No. 11 Tahun 2008 Tentang Informasi Dan Transaksi Elektronik Bab I Ketentuan Umum Pasal 1 ayat 6 bahwa Penyelenggaraan Sistem Elektronik adalah pemanfaatan sistem elektronik oleh penyelenggara negara, Orang, Badan Usaha, dan/atau masyarakat. Pemanfaat sistem elektronik sesuai dengan pertimbangan dalam UU ITE huruf c. bahwa perkembangan dan kemajuan Teknologi Informasi yang demikian pesat telah menyebabkan perubahan kegiatan kehidupan manusia dalam berbagai bidang yang secara langsung telah mempengaruhi lahirnya bentuk-bentuk perbuatan hukum baru;

Adapun tujuan pemanfaat IT menurut ketentuan pertimbangan huruf $d$. bahwa penggunaan dan pemanfaatan Teknologi Informasi harus terus dikembangkan untuk menjaga, memelihara, dan memperkukuh persatuan dan kesatuan nasional berdasarkan Peraturan Perundang-undangan demi kepentingan nasional. Sedangkan tujuan haruslah didukung oleh pemerintah sebagai mana diatur dalam huruf f. bahwa pemerintah perlu mendukung pengembangan Teknologi Informasi melalui infrastruktur hukum dan pengaturannya sehingga pemanfaatan Teknologi Informasi

${ }^{1}$ Ishaq, Dasar-dasar Ilmu Hukum, Sinar Grafika, cetakan ke 3, Jakarta, 2012, hlm. 118. 
dilakukan secara aman untuk mencegah penyalahgunaannya dengan memperhatikan nilai-nilai agama dan sosial budaya masyarakat Indonesia.

Atas dasar pemanfaat sistem elektronik yang secara langsung telah mempengaruhi lahirnya perbuatan hukum baru terutama dalam sistem administarsi negara, maka tindakan administrasi negara perlu didukung pemerintah dengan pengembangan teknologi informasi melalui infrastruktur hukum dan pengaturannya. Menurut C. Van Vollenhoven, Tindak administrasi negara sebagai pemeliharaan kepentingan dan rakyat secara spontan dan tersendiri oleh penguasa tinggi dan rendah (prinsip hierarki) ${ }^{2}$.

Dengan demikian penyelenggaraan sistem administrasi negara yang berbasis elektronik atau sistem komputerisasi sudah seharusnya menjadi bagian hukum administrasi negara modern sesuai perkembangan globalisasi. Sehingga sistem administrasi negara dapat mengantisipasi penyimpangan dalam penyelenggaraan negara baik oleh pemerintah, badan negara, masyarakat bahkan individu dalam kaitan dengan sistem adminiastrasi negara, misal berkaitan dengan masalah kewarganegaraan, tindak pidana, serta masalah perjanjian dan perizinan yang saat ini menjadi persoalan dalam dunia hukum baru. Rumusan Masalah dalam penelitian ini adalah :

1. Apakah arti tindakan/perbuatan hukum dalam sistem hukum administrasi negara!

2. Bagaimana peranan sistem elektronik dan informasi dalam penyelenggaraan sistem hukum administrasi negara?

\section{METODE}

Penulisan Jurnal menggunakan study literatur atau kepustakaan yaitu meneliti dan membaca pendapat para ahli dan menganalis tulisan ilmiah lainnya seperti jurnal,artikel serta peraturan perundang-undangan yang kemudian disusun dalam suatu bentuk tulisan secara ilmiah.

\footnotetext{
${ }^{2}$ Dalam Safri Nugraha, Hukum Administrasi Negara, CLGS, Fakultas Hukum UI, Jakarta,
} 2007, Hlm. 86. 


\section{PEMBAHASAN DAN ANALISIS}

Di dalam membahas penyelenggaraan sistem elektronik dalam sistem Hukum administrasi negara menurut UU ITE No. 11 Tahun 2008 Jo UU No. 19 Tahun 2006, di analisis berdasarkan pendapat ahli, peraturan perundang-undangan serta jurnal dan artikel yang berhubungan dengan sistem administrasi negara terutama menyangkut tindakan/perbuatan administrasi negara yang berbasis komputer atau elektronik.

\section{A. Tindakan/Perbuatan Hukum dalam Sistem Hukum Administrasi Negara}

Arti Perbuatan hukum menurut sistem hukum Administrasi Negara adalah perbuatan hukum timbul dari perbuatan manusia yang menimbulkan hak dan kewajiban untuk memenuhi kebutuhan manusia. Pengertian perbuatan hukum menurut ilmu hukum dan sistem hukum administrasi negara dapat dibagi menurut para ahli dan menurut hukum diantaranya. Menurut Ilmu hukum bahwa perbuatan hukum memiliki arti sebagai berikut :

a. R. Soeroso bahwa perbuatan hukum adalah setiap perbuatan subjek hukum (manusia dan badan hukum) yang akibatnya diatur oleh hukum, karena akibat itu bisa dianggap sebagai kehendak dari yang melakukan hukum ${ }^{3}$.

b. Chainur Arrasjid, perbuatan hukum adalah setiap perbuatan yang akibatnya diatur oleh hukum dan akibat itu dikehendaki oleh yang melakukan perbuatan ${ }^{4}$.

Dari pengertian perbuatan hukum maka unsur-unsur perbuatan hukum meliputi :

1. Perbuatan harus dilakukan oleh subjek hukum.

2. Perbuatan akibatnya diatur oleh hukum.

3. Perbuatan itu akibatnya dikehendaki oleh yang melakukan perbuatan itu.

Pembahasan mengenai Perbuatan hukum selalu dikuti oleh bukan perbuatan hukum, hal ini untuk melihat bahwa perbuatan hukum ada yang tidak dilarang dan ada juga yang melawan hukum. Oleh karena itu dalam perbuatan hukum unsur yang paling esensial adalah pernyataan kehendak. Pernyatataan

${ }^{3}$ R. Soeroso, Pengantar Ilmu Hukum, Sinar Grfika, Jakarta, 1996, hlm. 291.

${ }^{4}$ Chainur Arrasjid, Dasar-dasar Ilmu Hukum, Sinar Grafika , Jakarata, 2004, hlm. 136. 
kehendak harus ada juga dalam sistem hukum administrasi negara. Menurut R, Soeroso pernyataan kehendak pada asasnya tidak terikat pada bentuk-bentuk tertentu dan tidak ada pengecualinnya, sebab dapat terjadi secara tegas dan secara diam-diam. ${ }^{5}$

Di dalam Hukum administrasi negara klasifikasi tindak administrasi negara berdasarkan akibatnya bahwa tindak administrasi negara ada yang berakibat hukum dan tidak berakibat hukum. ${ }^{6}$ Contoh Wajib pajak melakukan penundaan pembayaran pajak tetapi tetap memiliki akibat hukum yaitu denda atau pengurangan. Sedangkan yang tidak berakibat hukum misalnya menganjurkan gerakan kebersihan.

Perbuatan atau tindakan hukum administrasi negara tentunya harus memenuhi unsur perbuatan hukum yaitu dilakukan oleh subjek hukum, diatur oleh hukum dan dikendaki oleh subjek hukum. Oleh sebab itu untuk memperjelas arti tindak hukum dalam sistem hukum administrasi negara perlu dipahami: pertama pengertian tindak administarsi negara, kedua Jenis tindak administrasi negara dan ketiga adalah klasifikasi tindak administarasi negara.

Pertama, Pengertian Tindak administrasi Negara dapat didifinisikan menurut pendpat para ahli dan menurut hukum. Menurut para ahli adalah ${ }^{7}$ :

a. C. Van Vollenhoven, Tindak administrasi negara sebagai pemeliharaan kepentingan dan rakyat secara spontan dan tersendiri oleh penguasa tinggi dan rendah (prinsip hierarki).

b. Romeyn, Tindak adaministrasi negara adalah setiap tindakan/perbuatan alat perlengkapan pemerintah ( Bestuurs organ), juga lapangan hukum tata pemerintahan. Misalnya keamanan peradilan yang bermaksud menimbulkan akibat hukum di bidang hukum administrasi.

c. Van Poelje, adalah tindakan pemerintah merupakan manisfestasi atau perwujudan bestuur.

${ }^{5}$ Op cit, hlm. 291-293.

${ }^{6}$ Safri Nugraha, Hukum Administrasi Negara, CLGS, Fakultas Hukum UI, Jakarta, 2007, Loc cit.

${ }^{7}$ Ibid, hlm. 86. 
Sedangkan menurut hukum arti tindak administrasi negara dikaitkan dengan Arti perbuatan hukum adalah perbuatan subjek hukum yang diberi akibat hukum oleh kaedah hukum tertentu, dan timbulnya akibat hukum memang dikehendaki oleh subjek hukum pelaku perbuatan tersebut ${ }^{8}$. Dalam sistem hukum administrasi negara perbuatan subjek hukum administrasi negara( Pejabat ) dapat dibagi dua macam yaitu ${ }^{9}$ :

1. Perbuatan yang bersifat Yuridis, yang menurut Pradjudi Atmosudirdjo meliputi: Penetapan (Beschiking, administrative , discretion). Rencana, Norma jabaran dan legislasi semu.

2. Perbuat yang bersifat Non yuridis, yang dijalankan oleh pejabat pemerintah atau pejabat administrasi negara yakni meliputi :
a. Pemerintahan Negara
b. Manjemen adminstrasi negara
c. Pengendalian/pengawsan badan-badan usaha negara
d. Tata usaha negara.

Berdasarkan pengertian tindak administrasi negara baik menurut ahli dan hukum bahwa yang menjadi subjek hukum dalam sistem hukum administrasi adalah bisa penguasa sesuai hierarki, alat perlengkapan negara maupun pemerintah. Sedangkan kehendak yang dituju adalah bisa pemeliharaan kepentingan negara, rakyat dan juga keamanan peradilan dan perwujudan bestuur yaitu berupa pelayanan publik.

Kedua, Jenis-jenis Tidak administrasi Negara. Dalam melaksanakan tindakan administrasi negara didasarkan pada jenis tindakan hukum atau perbuatan hukum. Secara umum perbuatan hukum dapat dibagi tiga ${ }^{10}$ :
1. Perbuatan hukum bersegi satu
2. Perbuatan hukum bersegi dua dan
3. Perbuatan hukum bersegi banyak.

\footnotetext{
${ }^{8}$ Mochtar Kususmaatmadja dan Arief. B. Sidharta, Pengantar Ilmu Hukum, Alumni, Bandung, 2000, Hlm. 86-87.

${ }^{9}$ Jum Anggraini, Hukum Administrasi Negara, Graha Ilmu, Yogyakarta, 2012, hlm. 104.

${ }^{10}$ Ishaq, op cit, hlm. 125.
} 
Tindakan administrasi negara dalam sistem hukum adminitrasi negara secara garis besar dibagi dua yaitu :

a. Tindak Administrasi Negara dalam bidang Hukum Publik

Adalah tindakan hukum sepihak yang dilakukan pemerintah yang dilaksanakan berdasarkan wewenang yang laur biasa. (Menurut Prins artinya kekuasaan diperoleh dari Undang-undang yang diberikan khusus pada pemerintah dan tidak pada badan swasta) ${ }^{11}$.

Tindak administrasi negara dalam hukum publik meliputi bersegi dua dan bersegi satu. Bersegi dua lebih tertuju pada perjanjian yang diatur oleh hukum publik bukan hukum perdata. Sedangkan bersegi satu yaitu tindak administrasi negara yang menhasilkan keputusan seperti penagturan, rencana, norma jabaran dan legislasi semu, penetapan.

b. Tindak Administrasi Negara dalam bidang Hukum Privat

Administrasi negara melakukan hubungan hukum dengan subjek hukum lain berdasarkan hukum privat. Menurut Indroharto, para pihak bebas menentukan perjajian, walaupun pada dasarnya dibatasi undang-undang. ketentuan Undangundang bersifat memaksa untuk bentuk perjanjian. Sementara itu, isi perjanjian bergantung pada kesepakatan para pihak ${ }^{12}$.

Ketiga adalah klasifikasi tindak administarasi negara dapat dilihat dari berbagai segi yaitu :

1. Segi sifatnya, terdapat tindak administrasi negara yang bersifat perintah, pelayanan dan pembangunan. Contoh panggilan pengadilan dan pelayanan.

2. Segi akibat, yaitu ada yang berakibat hukum dan tidak berakibat hukum.

3. Segi daya lakunya, ada yang bersifat umum dan khusus.

4. Segi Oposabilitas (Dapat ditentang), dapat berupa intern dan ektern.

5. Segi manifestasi kehendak, yaitu bilateral, uniateral dan multilateral.

6. Segi struktur, ada yang berstruktur sederhana dan kompleks.

\footnotetext{
${ }^{11}$ Pendapat Prins dalam buku Safri Nugraha, op cit, hlm. 89.

${ }^{12}$ Indroharto, Usaha memahami Undang-undang tentang Peradilan Tata Usaha Negara, Pustaka Sinar Harapan, Jakarta, 1996, hlm. 72-73.
} 
7. Segi jangka waktu berlakunya, ada yang berlaku satu kali dan saat itu dan ada jangka waktu terus-menerus.

\section{B. Peranan Sistem Elektronik dan Informasi dalam Penyelenggaraan Sistem Hukum Administrasi Negara.}

Peranan sistem elektronik dan informasi dalam penyelenggaraan sistem hukum administrasi negara didasarkan pada keberlakuan hukum atau kaedah hukum administrasi negara. Hal ini karena dalam sistem elektronik ada tiga hal penting yang berkaitan dengan sistem hukum administrasi negara yaitu Teknologi informasi, dokumen elektronik dan sertifikat elektronik.

Ada tiga landasan hukum berlakunya kaedah hukum untuk menentukan sahnya suatu sistem elektronik dalam penyelenggaraan sistem hukum administrasi negara meliputi ${ }^{13}$ :

1. Landasan Yuridis, suatu kaedah hukum administrasi negara akan sah karena :

a. Sesuai prosedur dalam proses penentuannya atau pembuatannya.

b.Sesuai dengan pertingkatan hukum (hierarki perundang-udangan)

c. Sesuai sistem/tertib hukum secara keseluruhan.

d. Adanya ikatan yang memaksa untuk bertindak.

2. Landasan Sosiologis, yaitu berdasarkan kepada penerimaan masyarakat terhadap kaedah hukum yaitu:

a. Adanya pengakuan dan penerimaan oleh masyarakat.

b. Adanya unsur paksaan dari penguasa atau pejabat hukum agar dipatuhi masyarakat.

3. Landasan Filosofis, sesuai dengan cita-cita hukum agar tercipta kedamaaian dan keadilan. Yang meliputi lingkup wilayah, pribadi, masa dan ikhwal.

Dalam UU No.19 Tahun 2006 tentang ITE Pasal 6. Bahwa

Penyelenggaraan Sistem Elektronik adalah Pemanfaatan Sistem Elektronik oleh

\footnotetext{
${ }^{13}$ Ishaq, op cit, hlm. 44.
} 
penyelenggara negara, Orang, Badan Usaha, dan/atau masyarakat. Sedangkan dalam Pasal 1 ayat 6a. bahwa Penyelenggara Sistem Elektronik adalah setiap Orang, penyelenggara negara, badan usaha, dan masyarakat yang menyediakan, mengelola,dan/atau mengoperasikan Sistem Elektronik, baik secara sendirisendiri maupun bersama-sama kepada pengguna Sistem Elektronik untuk keperluan dirinya dan/atau keperluan pihak lain.

Agar penyedian, pengelolahan dan pengoperasian sistem elektronik dapat berlaku dengan sah dalam sistem administrasi negara maka haruslah didasarkan pada keberlakuan yuridis yaitu landasan yang sah baik itu prosedur pembuatannya dibuat oleh lembaga yang sah menurut Undang-undang. Peraturan yang dibuat dalam sistem elektoknik harus sesuai dan tidak bertentangan dengan peraturan diatasnya, bila dilihat dari peraturan tentang sistem elektronik ini sudah sesuai dengan hierarki perundangan-undandangan bahwa tujuan penyelenggaraannya untuk kesejahteraan rakyat (Dalam UUD 1945). dan sudah sesuai dengan tertib hukum yaitu tidak bertentangan dengan kepentingan umum. Dan bila melanggar UU ITE akan dikenakan sanksi baik pidana, perdata dan administrasi negara.

Sedangkan berdasarkan keberlakuan sosiologis bahwa sistem elektronik harus Adanya pengakuan dan penerimaan oleh masyarakat dan adanya unsur paksaan dari penguasa atau pejabat hukum agar dipatuhi masyarakat. Disini keabsahan dokumen dan teknologi informasi serta sertifikat elektronik yang digunakan dan dihasilkan harus mendapat pengakuan dan penerimaan dari masyarakat berdasarkan standar nasional bahkan internasional yang dikeluarkakan oleh lembaga yang resmi dan diakui negara Indonesia. Sehingga tindakan administrasi negara akan diakui dan hasil aktivitasnya juga menjadi sah karena adanya penerapan hukum atau peraturan yang memiiliki sanksi yang jelas dan prosedur yang suadah diterima masyarakat.

Dan berdasarkan keberlakuan filosofis agar tercipta kedamaaian dan keadilan dimana penyelenggaraan sistem elektronik dalam sistem adminitrasi negara didasarkan pada lingkup wilayah, pribadi, masa dan ikhwal. Disini didalam memberikan teknologi informasi dan dokumen dan sertifikat harus 
memakai konsep kedamaian dan keadilan. Konsep kedamaian berarti tidak ada gangguan ketertiban dan juga tidak ada kekangan terhadap kebebasan. ${ }^{14}$ Dengan demikian tidak ada ancaman baik dari dalam maupun dari luar terhadap dokumen yang dibuat. Sedangkan konsep keadilan adalah pemeliharaan tata hukum positif malalui penerapannya yang benar-benar sesuai dengan jiwa tata hukum positif tersebut ${ }^{15}$. Keadilan dapat dibagi dua yaitu pertama keadilan distributif atau subjektif dimana sesuai jasa dan kedudukan dalam masyarakat sedangkan kedua keadilan korektif atau objektif yaitu pemberlakuan secara sama tanpa pandang bulu. Dengan Sistem elektronik dalam penyelenggaraan sistem administrasi negara haruslah diberlakukan sama terhadap masyarakat, seperti dalam memberikan sertifikat, dokumen elektronik serta memberikan informasi teknologi

Sehingga peran sistem elektronik dalam penyelenggaraan sistem adminitrasi negara haruslah memenuhi prinsip atau asas keberlakuan hukum secara yuridis, sosiologis dan filosofis.

\section{KESIMPULAN}

1. Tindakan/Perbuatan Hukum dalam Sistem Hukum Administrasi Negara adalah setiap tindakan/perbuatan alat perlengkapan pemerintah ( Bestuurs organ) dalam lapangan hukum tata pemerintahan untuk pemeliharaan kepentingan rakyat dalam bidang hukum publik dan privat dengan wewenang luar biasa dari Undang-undang baik itu bersegi satu, dua dan segi banyak.

2. Peranan Sistem Informasi dan Elektornik dalam Penyelenggaraan Sistem Hukum Administrasi Negara adalah Untuk memanfaatkan sistem teknologi informasi, dokumen elektronik dan sertifikat elektronik dengan prinsip yuridis, sosiologis dan filosofis.

\section{DAFTAR PUSTAKA}

\section{Buku-buku}

Chainur Arrasjid, Dasar-dasar Ilmu Hukum, Sinar Grafika, Jakarata, 2004,

\footnotetext{
${ }^{14}$ Ishaq, ibid, hlm. 7.

${ }^{15}$ Ibid.hlm 8.
} 
Indroharto, Usaha memahami Undang-undang tentang Peradilan Tata Usaha Negara, Pustaka Sinar Harapan, Jakarta, 1996.

Ishaq, Dasar-dasar Ilmu Hukum, Sinar Grafika, cetakan ke 3, Jakarta, 2012.

Jum Anggraini, Hukum Administrasi Negara, Graha Ilmu, Yogyakarta, 2012.

Mochtar Kususmaatmadja dan Arief. B. Sidharta, Pengantar Ilmu Hukum, Alumni, Bandung, 2000.

R. Soeroso, Pengantar Ilmu Hukum, Sinar Grfika, Jakarta, 1996,

Safri Nugraha, Hukum Administrasi Negara, CLGS, Fakultas Hukum UI, Jakarta, 2007.

\section{Peraturan Perundang-undangan}

UUD 1945 yang dimandemen

UU No. II Tahun 2008 Junto UU No.19 Tahun 2006 tentang Informasi dan Transaksi Elektronik. 